Egyptian Journal of Aquatic Biology \& Fisheries

Zoology Department, Faculty of Science,

Ain Shams University, Cairo, Egypt.

ISSN $1110-6131$

Vol. 24(7): $271-286$ (2020)

www.ejabf.journals.ekb.eg

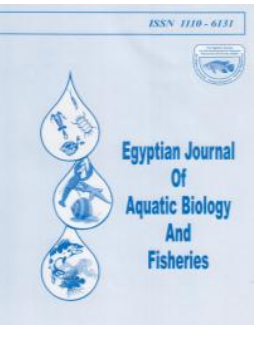

\title{
Evaluation of the toxicity of a systemic fungicide (FOLIETTE) in a freshwater macrophyte (Iris pseudacorus L.).
}

\section{Cheraitia Souad, Sbartai H.* and Sbartai I.}

Cellular Toxicology Labolatory, Departement of Biology, Faculty of Sciences, Badji Mokhtar-

Annaba University, P.B. N²12, 23000 Annaba, Algeria.

*Corresponding Author: sbartaihana@gmail.com

ARTICLE INFO

Article History:

Received: July 27, 2020

Accepted: Oct. 24, 2020

Online: Oct. 25, 2020

\section{Keywords:}

Aquatic pollution, FOLLIETTE,

Iris pseudacorus L., oxidative stress, tolerance.

\section{INTRODUCTION}

Aquatic contaminations pose many problems for organisms and the functioning of ecosystems, mainly caused by agricultural activity including fungicides. It is in this context that we conducted an ecotoxicological study to evaluate the toxicity of a (FOLIETTE) fungicide, commonly used in Algeria, in a freshwater macrophyte (Iris pseudacorus L.) from natural marshes in the "Bourdim region, El-Tarf located in the extreme northeast of Algeria" by measuring certain physiological and biochemical parameters. The results obtained show that the addition of this fungicide, at different concentrations for 7 days of treatment, decreases the content of chlorophyll pigment and increases the accumulation of total proteins in different parts of the plant (roots and leaves). Similarly, a significant increase in some stress biomarkers such as total polyphenols, malondialdehyde (MDA) and glutathione (GSH). At the same time, the measurement of enzyme activity involved in the detoxification system shows a significant induction of guaiacol-peroxidase (GPX) activity, which plays an important role in mitigating oxidative damage, thus proving the tolerance of our plant model to this xenobiotic and consequently its possible use as a candidate for phytorepuration.

Waste management in general is now a major environmental concern in many countries of the world. (Tshala et al., 2017). In particular, agricultural wastes that have deteriorated over time the aquatic ecosystem known for its fauna and floristic biodiversity. Faced with this threat, most countries have opted for conventional contaminated water treatment systems, but this technological choice has often proven to be highly inappropriate due to the very high cost of facilities and equipment, the lack of well-prepared technicians to maintain them, and the prioritization choices made by public 
powers, resulting in outdated equipment, overload and abandonment of structures (Suwasa and Wanida, 2011). Furthermore, the sanitation systems to be considered must be flexible and scalable. However, to provide solutions to this problem there are known alternatives both from a technical point of view and from a socio-economic point of view such as natural methods of waste water treatment which is phytopurification. (Bensmina-Mimeche et al., 2013; Bensaid et al., 2017). This procesus involves replicating and potentiating on a reduced scale the purification processes that take place in natural wetlands and are based on the joint action of plants, microorganisms and soil (Vymazal, 2005). These are artificial wetlands or also known as macrophyte planted filters (Suwasa and Winda, 2011). The installation of artificial marshes at outfalls of domestic sewage treatment plants (Leto et al., 2013), road runoff (Triboit et al., 2009) or agricultural drains (Destandau et al., 2013) is increasingly widespread (Prost-Boucle and Boutin, 2013). However, this treatment system is still rarely used in Algeria to reduce any form of aquatic pollution, particularly that caused by agricultural activity. We can cite the two natural lagoon treatment plants at N'Goussa-Ouargla and the M'zabGhardaia valley. It is in this context that our study was carried out, which consists in assessing in semi-controlled conditions the tolerance of the studied helophyte (Iris pseudacorus L.) against systemic fungicide widely used in Algeria (FOLIETTE) and to test the purifing functionality of this species as an alternative solution to the treatment of water contaminated by this xenobiotic.

\section{MATERIALS AND METHODS}

\section{Biologicol material}

The wetar flag (Iris pseudacorus L.) is a bulbous or rhizomatous perennial herbaceous plant of the Iridaceae family. It is characterized by pink rhizomes, with stems generally simple or little branched, the leaves are mainly basal, dark green, 40 to $100 \mathrm{~cm}$

long and 1 to $4 \mathrm{~cm}$ wide with thick mid-areas. This helophyte contains four to twelve flowers that are arranged in inflorescences on stems 2 to $5 \mathrm{~cm}$ long. The flowers are pale yellow to bright yellow and 8 to $10 \mathrm{~cm}$ in diameter (Stone, 2009).

\section{Chemical material}

The study focused on a very widely used fungicide in Algeria (FOLIETTE). It is a systemic fungicide with protective and curative action against many parasitic fungi, especially of the order of phycomycetes and Oomycota. The FOLIETTE is based on $80 \%$ fosetyl-aluminum (Aluminium Tris (-O-ethyl phosphonate), an organometallic compound, of the phosphanate group (Bayer Jardin, 2011). 
Table.1. Chemical structure of active substance of FOLIETTE.

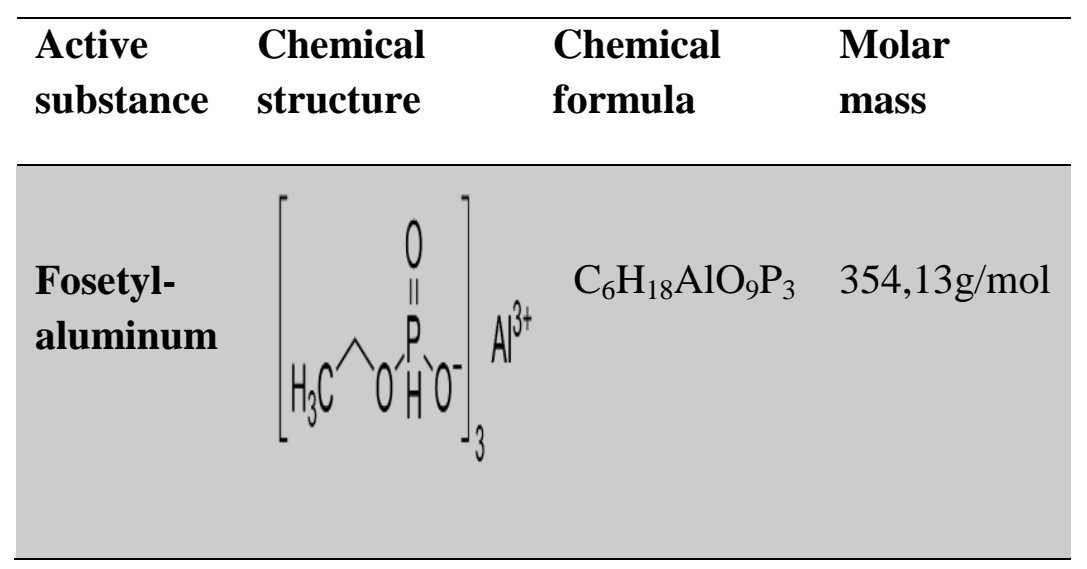

\section{The experimental device}

The experimental pilot consists of four rectangular glass aquariums $40 \mathrm{~cm}$ long and $30 \mathrm{~cm}$ wide filled from bottom to top with $5 \mathrm{~cm}$ of gravel and $15 \mathrm{~cm}$ of sand substrate. Carefully harvested yellow iris plants from the natural marshes of Bourdim, commune of Bouteldja, wilaya-El-Tarf, were freshly cultivated, under semi-controlled conditions, on average three plants per tank for 7 days which represents the duration of the treatment with the Foliette in the open field. The feed of the beds (the third layer), $20 \mathrm{~cm}$ thick, is composed of contaminated pond water with different concentrations of FOLIETTE: $(0 ; 37.72 ; 75.44 ; 150.88 \mu \mathrm{g})$. The latter were chosen from the regulatory standards for the use of this fungicide in agriculture from a biological and toxicological point of view.

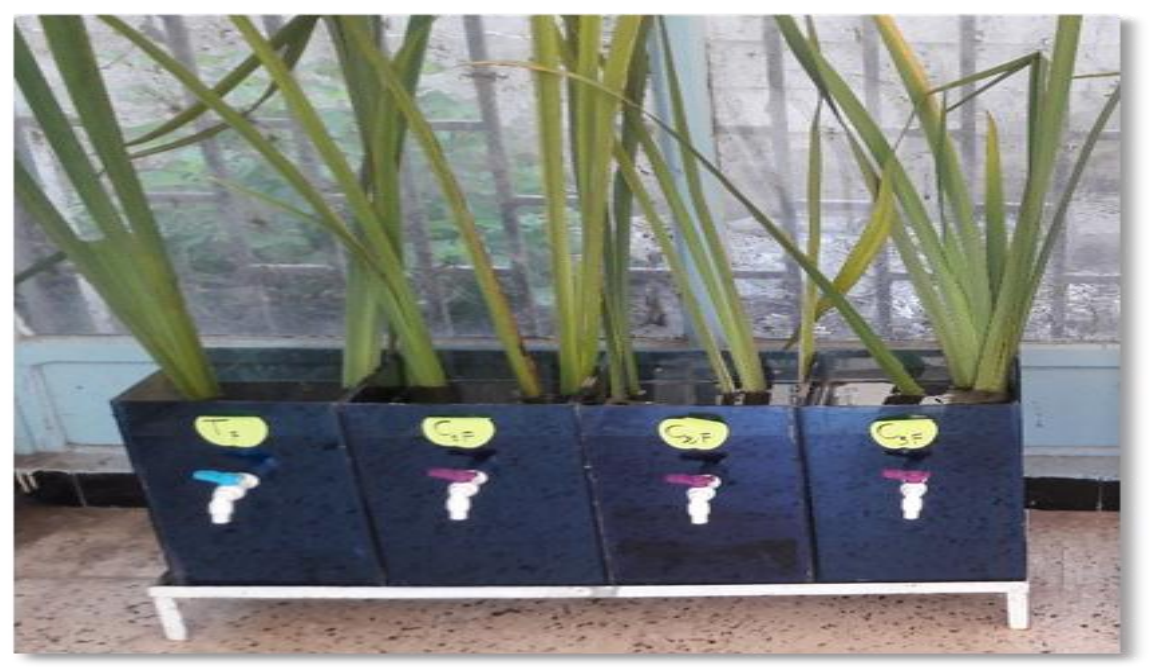

Figure.1. Experimental design. (personal hold). 
Table. 2. List of acronyms.

\begin{tabular}{ll}
\hline Aconyms & Nomenclature \\
\hline C & Control $=0 \mu \mathrm{g}$ \\
$\mathbf{C 1}$ & Low Concentration $=37.72 \mu \mathrm{g}$ \\
C2 & Medium concentration $=75.44 \mu \mathrm{g}$ \\
$\mathbf{C 3}$ & High concentration $=150.88 \mu \mathrm{g}$. \\
$\mathbf{C h l}$ & Chlorophyll. \\
$\mathbf{c m}$ & Centimeter \\
DM & Dry material. \\
FM & Fresh material. \\
L & Leaves. \\
Prot & Protein. \\
R & Roots. \\
GAE & Gallic Acid equivalent \\
\hline
\end{tabular}

\section{STUDIED PARAMETERS}

\section{Measurement of photosynthetic pigments: $(a),(b)$ and $(a+b)$}

The chlorophyll content is determined by the traditional method of (Holden, 1975). For each treatment, one weighs $1 \mathrm{~g}$ of the leaves of the plant, which is cut into small pieces and ground in a mortar with $25 \mathrm{ml}$ of acetone titrated to $80 \%$ and with a pinch of calcium carbonate $\left(\mathrm{CaCO}_{3}\right)$. After filtration, the solution is put in black boxes to prevent oxidation of chlorophyll by light. Dosing is done by taking $3 \mathrm{ml}$ of the solution from the spectrophotometer tank. Reading is done at wavelengths 645 and $663 \mathrm{~nm}$, after calibration of the apparatus with the $80 \%$ acetone control solution. The concentration of these chlorophyll pigments was calculated according to the formula of (Arnon, 1949), is expressed in $(\mu \mathrm{g} / \mathrm{g}$ of FM).

\section{Dosage of total protein}

The foliar and root proteins in I.pseudacorus are assayed by colorimetry according to the method of (Bradford, 1976), which consists in measuring the concentration of proteins in solution by spectroscopic analysis, and $0,1 \mathrm{~g}$ of fresh vegetable material is milled with $10 \mathrm{ml}$ of distilled water. After filtration, $0.2 \mathrm{ml}$ of the supernatant is withdrawn and $2 \mathrm{ml}$ of CBB (Coomassie Brilliant Blue) is added. The principle of the method is based on the fixing of the dye $(\mathrm{CBB})$ on the proteins at the level of basic and aromatic residues, this fixing causes a transfer of its color which passes from red to blue. This color change is measured at a wavelength of $595 \mathrm{~nm}$, using Bovine Serum Albumin (BSA) as standard. 


\section{Determination of certain biomarkers of stress Dosage of malondialdehyde (MDA)}

Lipid peroxidation is estimated at the content of malondialdehyde (MDA) determined according to the method described by (Alia $\boldsymbol{e t}$ al., 1995). Homogenization of the plant tissue in $5 \%$ trichloroacetic acid (TCA) at $10 \mathrm{ml}$ per $1 \mathrm{~g}$ of plant tissue is followed by centrifugation for $15 \mathrm{~min}$ at $12000 \mathrm{~g}$. The name of the parade is added at a volume equal to thiobarbituric acid (to be determined) at $0.5 \%$ prepared in the (TCA) at $20 \%$. The mixture is incubated at $100{ }^{\circ} \mathrm{C}$ for $30 \mathrm{~min}$. Then the reaction is by placing the tubes in an ice bath. The absorbance of the name, obtained after centrifugation at $10000 \mathrm{~g}$ for $5 \mathrm{~min}$, was $532 \mathrm{~nm}$. The concentration of MDA is used as extension coefficient: 155 $\mathrm{mM}^{-1} \mathrm{~cm}^{-1}$. The concentrations of MDA are expressed in ( $\mu \mathrm{M} / \mathrm{mg}$ of protein).

\section{Dosage of glutathione (GSH)}

The enzymatic extract $(800 \mu \mathrm{l})$ is homogenized in a solution of (Tris / EDTA) and de proteinized by $0.25 \%$ sulpho-salicylic acid (SSA). After centrifugation at $2000 \mathrm{~g}$ for 10 minutes, the supernatant is used for the spectrophotometric assay with the reagent (DTNB) at $0.01 \mathrm{M}$ to $412 \mathrm{~nm}$. The concentrations of GSH are determined by the method of (Weckbecker and Cory, 1988) is expressed in ( $\mu \mathrm{mol} / \mathrm{mg}$ of protein).

\section{Dosage of total polyphenols}

The extracts of the different plant parts (roots and leaves) were prepared by maceration of $100 \mathrm{mg}$ of powder of each mash in $10 \mathrm{ml}$ of methanol (70\%) overnight at room temperature $\left(20{ }^{\circ} \mathrm{C}\right.$ to $\left.25{ }^{\circ} \mathrm{C}\right)$. Finally, the maceras were filtered cold through a filter paper. The total phenol content of the extracts was determined by the method of (Kim et al., 2003). $0.5 \mathrm{ml}$ of the extract is mixed with $0.45 \mathrm{ml}$ of distilled water and 0.5 $\mathrm{ml}$ of the Folin-Ciocalteu reagent. After 5 minutes, $5 \mathrm{ml}$ of a $7 \%$ sodium carbonate $\left(\mathrm{Na}_{2} \mathrm{CO}_{3}\right)$ solution was added to the mixture with stirring. After incubation in the dark for $90 \mathrm{~min}$ at $23^{\circ} \mathrm{C}$ the optical density of each prepared solution was read by a spectrophotometer at $750 \mathrm{~nm}$. For each sample prepared five replicates were planned. Quantification of the total polyphenols was done using a calibration curve of different dilutions of gallic acid $(150 ; 100 ; 80 ; 60$; and $40 \mathrm{mg} / 1)$. From a stock solution (gallic acid) of $200 \mathrm{mg} / 1$ dissolved in water. This curve is performed under the same operating conditions as the samples. The trend curve obtained in our case is ( $\mathrm{Y}=0.0037 \mathrm{X}+$ $0.0664)$ with $\left(\mathrm{R}^{2}=0.9516\right)$. The polyphenol contents are expressed in $\mathrm{mg}$ of gallic acid equivalent per gram of dry matter (mg GAE.g ${ }^{-1}$ of DM).

\section{Assay of guaiacol-peroxidase (GPX) activity}

The activity guaiacol-peroxidase (GPX) is determined spectrophotometrically (Jenway spectrophotometer 6300) at $470 \mathrm{~nm}$ by the technique of (Hiner $\boldsymbol{e t}$ al., 2002). The molar linear extinction coefficient used is $=2470 \mathrm{M}^{-1} \mathrm{~cm}^{-1}$. For a final volume of $3 \mathrm{ml}$, $100 \mu \mathrm{l}$ of enzymatic extract, $50 \mu \mathrm{l}$ of $0.03 \% \mathrm{H}_{2} \mathrm{O}_{2}$ and $2850 \mu \mathrm{l}$ of phosphate-guaiacol buffer (50 mM NaK, $8 \mathrm{mM}$ guaiacol, $\mathrm{pH} 7,2) \mathrm{GPX}$ is expressed in $\mathrm{nmol} / \mathrm{min} / \mathrm{mg}$ of protein. 


\section{STATISTIC STUDY}

The results obtained were expressed by the average of three replicates (the standard deviation). The averages of the same series were compared between them, using the statistical test, analysis of the variance to a classification factor according to the increasing concentrations of FOLIETTE, with a significance level $(\mathrm{P})$. Calculations of this test were performed using statistical analysis software MINITAB version 16.0.

\section{RESULTS}

\section{Effect of FOLIETTE on chlorophyll content in the leaves of I.pseudacorus}

Table 3, represents the impact of FOLIETTE on photosynthetic pigments in I. pseudacorus showed a significant decrease $(\mathrm{P} \leq 0.001)$ in chlorophyll content $(a, b$ and $a$ $+b)$ as a function of increasing concentrations compared to control leaves. The lowest values of chl $a$, Chl $b$ and $\mathrm{Chl}(a+b)$ are recorded in the leaves exposed to $\mathrm{C} 3$ compared to the control values.

Tab. 3. Effect of FOLIETTE on chlorophyll content $(\mathrm{mg} / \mathrm{g})$ in the leaves of I.pseudacorus after 07days of treatment.

\begin{tabular}{llll}
\hline Samples & Chl $\boldsymbol{a}$ & $\mathbf{C h l} \boldsymbol{b}$ & $\mathbf{C h l}(\boldsymbol{a}+\boldsymbol{b})$ \\
\hline $\mathbf{L C}$ & $5.12 \pm 0.04$ & $20.80 \pm 0.38$ & $25.92 \pm 0.34$ \\
$\mathbf{L C}_{\mathbf{1}}$ & $4.61 \pm 1.44$ & $18.50 \pm 5.75$ & $23.10 \pm 7.21$ \\
$\mathbf{L C}_{\mathbf{2}}$ & $4.25 \pm 1.35$ & $16.82 \pm 5.51$ & $21.06 \pm 6.87$ \\
$\mathbf{L C}$ & $3.96 \pm 1.32$ & $15.62 \pm 5.35$ & $19.58 \pm 6.67$ \\
\hline
\end{tabular}

\section{Effect of FOLIETTE on total Protein rates in the roots and leaves of I.pseudacorus.}

The variations in total protein rates in the roots and leaves of yellow flag iris are illustrated in figure 2. the significant increase $(\mathrm{P} \leq 0.001)$ in total protein levels in the roots and leaves treated with increasing FOLIETTE concentrations. The highest value $(118.2 \mu \mathrm{g} / \mathrm{g}$ of FM) is observed in roots at the highest concentration compared to the control value $(58.56 \mu \mathrm{g} / \mathrm{g}$ of $\mathrm{FM})$. On the other hand, treatment with FOLIETTE significantly decreases $(\mathrm{P} \leq 0.001)$ the protein content in stressed leaves as a function of increasing concentrations but these values remain above the control valu. 


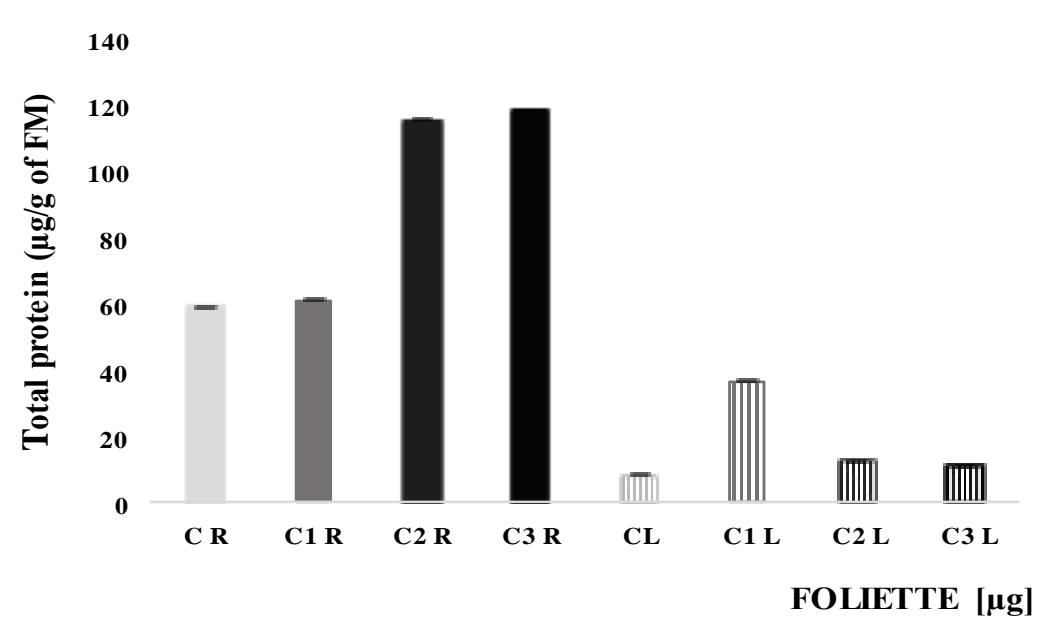

Figure.2. Effect of FOLIETTE on the total protein content in the roots and leaves of $\boldsymbol{I}$. pseudacorus after 07days of treatment.

\section{Effect of FOLIETTE on certain stress biomarkers}

Effect of FOLIETTE on malondialdehyde (MDA) level in the roots and leaves of $I$. pseudacorus

According to figure 3, which represents the variations of the level of MDA according to the increase of the concentrations of FOLIETTE, one observes a significant increase $(\mathrm{P} \leq 0.001)$ of this parameter in the roots of yellow iris compared to the value witness. These variations reach successively $(0.017 ; 0.040$ and $0.069 \mu \mathrm{M} / \mathrm{mg}$ of prot) for $\mathrm{C} 1$; C2 and C3 of FOLIETTE, an increase of 4, 6 and 8 times the control value (0.009 $\mu \mathrm{M} / \mathrm{mg}$ of prot). Likewise, a significant increase in the level of MDA is recorded in the leaves of Iris which reach its maximum $(0.036 \mu \mathrm{M} / \mathrm{mg}$ of prot $)$ for $\mathrm{C} 3$, ie twice the control value.

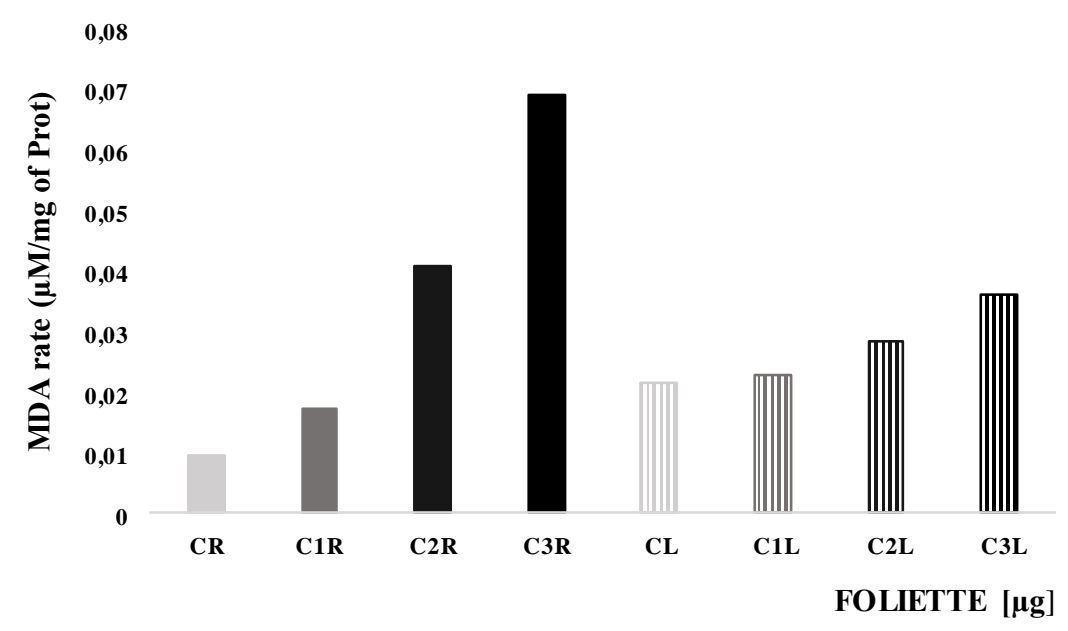

Figure.3. Effect of FOLIETTE on malondialdehyde (MDA) rate in the roots and leaves of the I.pseudacorus after 07days of treatment. 


\section{Effect of FOLIETTE on the quantity of glutathione (GSH) in the roots and leaves of I. pseudacorus.}

According to figure 4, there is a significant increase $(\mathrm{P} \leq 0.001)$ in the level of GSH for the low and medium concentration of FOLIETTE in the roots and the leaves of iris compared to the control organs. The highest level of glutathione $(0.664 \mu \mathrm{mol} / \mathrm{mg}$ Prot) is recorded in the leaves treated with $\mathrm{C} 2$ while a significant decrease is observed in the leaves treated with $\mathrm{C} 3$ which reaches $0.199 \mu \mathrm{M} / \mathrm{mg}$ Prot compared to the control value $(0.485 \mu \mathrm{M} / \mathrm{mg}$ Prot $)$, ie a decrease of $59 \%$.

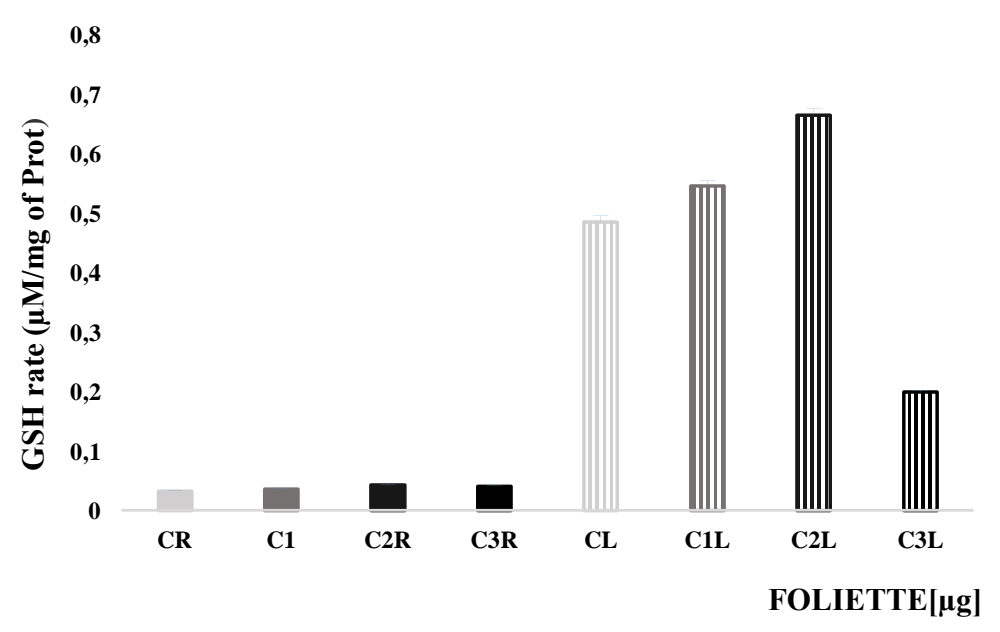

Fig.4. Effect of FOLIETTE on glutathione (GSH) rate in the roots and leaves of $\boldsymbol{I}$. pseudacorus after 07 days of treatment.

\section{Effect of FOLIETTE on total polyphenol levels in roots and leaves of I.pseudacorus.}

Based on the results illustrated in figure 5, the amount of total polyphenols increased dose-dependent relative to the control in I. pseudacorus roots. The greatest amount of total polyphenols (436.53 mg GAE / $\mathrm{g}$ of DM) is recorded for the high concentration, which is twice the control value (210.13 mg GAE g-1 of DM). In addition, we observed a significant increase in the rate of total polyphenols in iris leaf treated with different concentrations and reaches its maximum (254.13 mg EAG / g of DM) for the low concentration of $68 \%$ compared to control (151mg GAE g-1 of DM). 


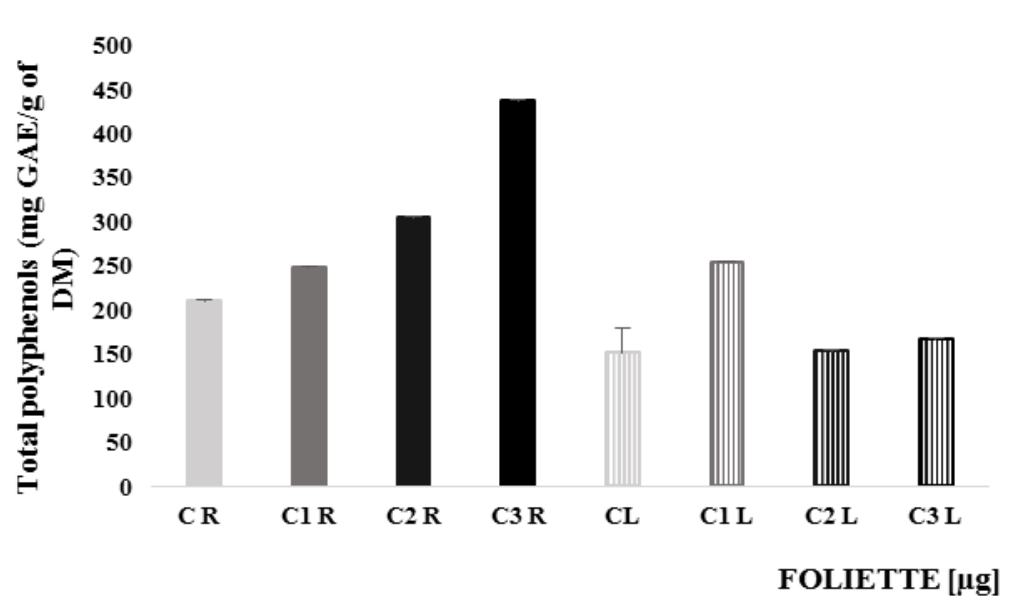

Fig. 5. Effect of FOLIETTE on total polyphenols rate in the roots and leaves of I.pseudacorus after 07 days of treatment.

Effect of FOLIETTE on gaiacol-peroxidase (GPX) activity in the roots and leaves of I. pseudacorus.

For this parameter, the results obtained are shown in figure 6, which detects a significant increase $(\mathrm{P} \leq 0.001)$ in GPX activity in roots and leaves of $\boldsymbol{I}$. pseudacorus as a function of the increasing concentrations of FOLIETTE. The highest values are recorded for the high concentration $\left(\mathrm{C}_{3}\right)$ successively in roots and leaves $(0.000206$ and 0.000202 $\mathrm{nM} / \mathrm{min} / \mathrm{mg}$ of Prot) compared to the control value.

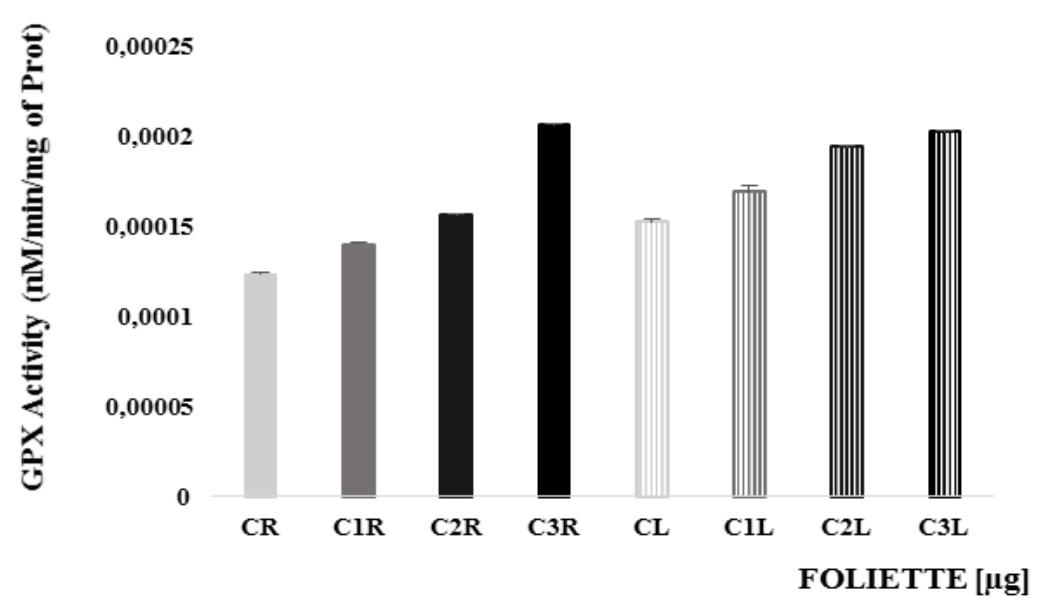

Figure. 6. Effect of FOLIETTE on gaiacol-peroxidase (GPX) activity in the roots and leaves of I.pseudacoru after 07 days of treatment. 


\section{DISCUSSION}

In our work we tested the chlorophyll levels that are considered to be excellent biomarkers of plant toxicity knowing that there is a strong correlation between cell densities and photosynthetic fluorescence parameters in environmental pollution (Dewez et al., 2007). Our results clearly show a decrease in chlorophyll foliar levels in yellow iris as a function of increasing fungicide concentrations relative to control leaves. This appears to agree with Elzbieta et al., (2011) on the phytotoxicity of a Roundup Ultra 360 SL herbicide in the waterlense: Lemna minor and Moldes et al., (2008) which suggest a decrease in chlorophyll content in glyphosate-treated soybean tissues. This decrease can be attributed to the inhibition of its biosynthesis and photo-destruction of the herbicide by reducing the formation of Aminolevulinic acid (ALA) as a porphyrin precursor. Similarly, Zaimeche, 2015 and Bensaid et al., 2017 noted a decrease in chlorophyll levels, respectively, at Lemna minor, Chlorella sp, Phragmites communis and Typha latifolia, exposed to various concentrations of trace metallic elements, related to the reduction in energy intake from chloroplasts to the photosynthetic system.

In contrast, the addition of different concentrations of FOLIETTE in the culture medium stimulates the synthesis of total proteins, particularly in roots such as Elodea canadensis and Lemna minor (Tlidjen et al., 2012) and (Derradji et al., 2014). This increase can be explained by the fact that the latter are considered the seat of resistance of the plant to different stresses because they are attached directly to the sediment through their active enzyme system (Zouainia et al., 2016). In addition, the work of (GardésAlbert et al., 2003) relates the increase in proteins to the fact that the plant seeks to protect its Morphophysiological integrity in response to the damage induced by xenobiotics. In other words, protein accumulation is a molecular stress tolerance strategy that is directly related to an overproduction of ROS (Mishra et al., 2006). In contrast, when stress persists and ROS are not neutralized, they can cause oxidation of proteins ranging from the simple oxidation of an amino acid to the fragmentation of the peptide chains, resulting in lower protein levels (Sbartai et al., 2015).

In parallel, a great deal of work has been carried out to demonstrate the action of certain stress biomarkers, in particular glutathione (GSH), malondialdehyde (MDA) and total polyphenols (Radic et al., 2009). GSH, which carries a thiol function, is a antioxidant system first line of defense that binds to toxic metabolites through its $\mathrm{SH}$ function (Yadav et al., 2010). During the treatment of I. pseudacorus with the low and medium concentration of FOLIETTE, we observed an increase in the level of GSH in the roots and the leaves treated compared to the controls. These results are in the same direction as those of Fabrizio et al., (2003) who showed an increase in this rate during cadmium stress in reeds: Phragmites australis, and those of Kamara and Pflugmacher, (2006) in two aquatic species: Phragmites australis and Quercus suber planted in polluted waters as well as those of (Nadgorska-Socha et al., 2012; Sbartai et al., 2015) for which 
the level of GSH increases with the plant's tolerance to stress. While the high concentration of the fungicide applied induces a decrease in the GSH content of the roots and leaves. These results are comparable to those reported by certain authors (Ducruix $\boldsymbol{e t}$ al., 2006), where the level of GSH decreases in response to stress induced by high concentrations of cadmium. This depression can be explained either by its direct binding to the xenobiotic or by the use of glutathione in the GST conjugation reaction (Regoli $\boldsymbol{e} t$ al., 1998; Canesi et al., 1999).

In fact, the cascade reactions of free radicals with biological molecules such as lipids lead to lipoperoxidation of cell membranes resulting in an increase in the intracellular level of MDA, considered to be one of the products of lipid peroxidation (Servais, 2004). The results of this work are comparable to those reported by Riffat $\boldsymbol{e t}$ al., (2007) in Lemna polyrrhiza, which indicate an increase in the level of MDA following cadmium stress, in Lemna minor in the presence of aluminum (Radic et al., 2009), in three varieties of durum wheat following exposure to different concentrations of $\mathrm{ZnO}$ nanoparticles (Chiahi et al., 2016) and in foams treated with different concentrations of NPK. Likewise, Agostineto et al., (2016) show that the application of all herbicides such as bentazon, iodosulfuron, metribuzin and metsulfuron $(2,4-$ dichlorophenoxyacetic acid) induces lipid peroxidation.

For total polyphenols involved in several functions including plant defense mechanisms (N'goran et al., 2019), an increase was observed in the root and leaf system of the iris. These results agree with those of (Amensour et al., 2009; Aidi Wannes et al., 2010) which report an increase in the biosynthesis of total polyphenols in plants stressed by some xenobiotics such as in Sylvana potato subjected to three phytosanitary products (herbicide, acaricide and fungicide), proving that secondary metabolites play a role in the tolerance of this species to different types of stress (Belmahel, 2019) and therefore their protection against free radicals (Parida et al., 2004).

Indeed, excessive amounts of pesticides can act as toxic and induce abiotic constraints in plants (Sunohara and Matsumoto, 2008). the latter have an effective enzymatic defense system to neutralize excess ROS to protect cells against oxidative damage (Gill and Tuteja, 2010). Induction of GPX activity, following treatment with different concentrations of FOLIETTE, may be due to the overproduction of $\mathrm{H}_{2} \mathrm{O}_{2}$ in the roots and leaves of I. pseudacorus. This strong GPX activity clearly shows its crucial role in the defense mechanisms of plants and their tolerance to different stress conditions (Zou et al., 2009). In addition, some authors have reported that there is a relationship between cell wall lignification, oxidative stress, and oxygen peroxide content (Chaoui and El Ferjani, 2005), suggesting that the latter may be considered as the signaling molecule under stress conditions triggering thus the lignification process which has only a defense mechanism adopted by plants to improve the unbalanced state of the cellular system (Wang et al., 2011). 


\section{CONCLUSION}

Phyto-purification is an ecological, efficient and economical means of purification and many macrophytes are distinguished by their role of filtration and water purification which depends on their resistance to the active ingredients causing possible side effects on their metabolism.

At the end of our experiment a battery of results was listed, the most important of which is the installation of an oxidative stress in response to the accumulation of xenobiotics in the macrophyte tissues leading to a decrease in the levels of chlorophyll and an increase in total proteins, enzymatic activity (GPX) and certain non-enzymatic stress biomarkers (GSH, MDA and total polyphenols). These defense mechanisms triggered by these plants show that they have the capacity to resist this type of stress and could constitute an interesting model for the rehabilitation of contaminated aquatic environments (phytoremediation) by non-organic fungicides, knowing that the marsh iris is already known for its ability to absorb heavy metals. This technique can be seen as a prospect for the future, both interesting as such, but also promising given the current craze for these techniques.

\section{REFERENCES}

Agostinetto, D. ; Perboni, L.T. ; Langaro, A.C. ; Gomes, J. ; Fraga, D.S. and Franco, J.J. (2016). Changes in photosynthesis and oxidative stress in whaet plants submitted to herbicides application. Planta Daninha, ViçosaMG.,34:19.

Aidi Wannes, W.; Mhamdi, B.; Sriti, J.; Ben Jemia, M.; Ouchikh, O.; Hamdaoui, G.; Kchouk, M.E. and Marzouk, B. (2010). Antioxidant activities of the essential oils and methanol extracts from myrtle (Myrtus communis var.italica L.) leaf, stem and flower. Journal of Food and Chemical Toxicology., $48: 1362-1370$.

Alia, K.V.S.K. ; Prasad, P. and Pardha, S. (1995). Effect of zinc on free radicals and proline in brassica and cajanus. Phytochemistry., 39 :45-47.

Amensour, M. ; Sendra, E. ; Abrini, J. ; Bouhdid, S. ; Pérez-Alvarez, J.A. and Fernndez-Lpez, J. (2009). Total phenolic content and antioxidant activity of myrtle (Myrtus communis) extracts, Nat. Prod. Commun., $4: 819-824$.

Arnon, D.I. (1949). Cooper enzymes in isolated chloroplasts polyphenoloxydase in Beta vulgaris. Plant Physiol., 24 : 1-25.

Bayer Jardin. (2011). Fiche de données de sécurité conformément au règlement (CE) No. 1907/2006 Version 1 / EU. Produit FOLIETTE.

Belmahel, N. (2019). Effets des traitements pesticides sur les composés phénoliques de la 
pomme de terre cultivée (Solanum tuberosum Var Sylvana). Mémoire de Master, Université Abdelhamid Ibn Badis-Mostaganem, p.32.

Bensaid, M.; Meksem Amara, L.; Meksem, N.; Ferfar, M. and Djebar, M.R. (2017). Responses of Typha latifolia subjected to metal stress. Journal of Biodiversity and Environmental Sciences (JBES)., 11: 9-14.

Bensmina-Mimeche, L. ; Debabeche, M. ; Seghairi, N. and Benameur, N. (2013). Capacité de filtres plantés de macrophytes pour l'épuration des eaux usées dans le climat semi-aride. Courrier du Savoir., 17 :33-37.

Bradford, M. (1976). A rapid and sensitive method for the quantification of microgram quantities of protein utilizing the principal of protein-Dye binding. Analytical biochem., $72: 248-254$.

Canesi, L. ; Viarengo, A. ; Leonzio, C. ; Filippelli, M. and Gallo, G. (1999). Heavy metals and glutathione metabolism in mussel tis- sues. Aquat Toxicol., 46 : 67-76.

Chaoui, A. and Ferjani, E. (2005). Effect of cadmium and copper on an antioxidant capacities, lignification and auxin degradation in leaves of pea (Pisum sativum L.) seedlings.C. R. Biol., $328: 21-31$.

Chiahi, N. ; Bouloudenine, M. ; Daira, N.H. ; Guerfi, N. and Brinis, L. (2016). L'impact des nanoparticules $\mathrm{ZnO}$ sur les paramètres physiologiques et biochimiques chez le blé dur (Triticum turgidum ssp. durum). Journal of new sciences, Agriculture and Biotechnology., 27 : 1549-1558.

Derradji, M. ; Souiki, L. ; Berrebbah, H. and Djebar, M.R. (2014). Assessment of the bacteriological contamination of the wastewaters in Annaba's main discharges (North-Eastern Algeria). IJB., 4 : 112-114.

Destandau, F. ; Imfeld, G. and Rozan, A. (2013). Regulation of diffuse pesticide pollution : Combining point source reduction and mitigation in stormwater wetland (Rouffach, France). Ecological Engineering., 60 : 299- 308.

Dewez, D. ; Didur, O. ; Vincent-Heroux, J. and Popovic, R. (2007). Validation of photosynthetic- fluorescence parameters as biomarkers or isoproturon toxic effect on alga Scenedesmus obliquus. Department of Chemistry. Enviromental Toxicology Research Center. TOXEN, 2101, Montreal, Quebec, Canada.

Durcuix, C. ; Junot, C. ; Fiévert, J.B. ; Villiers, F. ; Ezan, E. and Bourguignon, J. (2006). New insights into the regulation of phytochelation biosynthesis in A.thaliana cells from metabolite profiling analyses. Biochimie., 88 : 1733-1742.

Elzbieta, K. ; Cezary, S. ; Halina, M. ; Jozef, K. and Bogumil, L.S. (2011). Phytotoxicity of Roundup Ultra 360 SL in aquatic ecosystems : Biochemical evaluation with duckweed (Lemna minor L.) as a model plant. Pesticide Biochemistry and Physiology., 99 : 237-343.

Fabrizio, P. ; Maria, A.I. ; Stefania, P. and Angelo, M. (2003). Interaction of Cadmium with Glutathione and Photosynthesis in Developing Leaves and Chloroplasts of Phragmites australis (Cav.)Trin.ex Steudel. Plant Physiology., 
$133: 829-837$.

Hiner, A.N.; Raven, E.L.; Thorneley, R.N.; Garcia-Canovas, F. and RodriguezLopez, J.N. (2002). Mechanisms of compound I formation in heme peroxidases. J Inorg Biochem., 91:27-34.

Holden, M. (1975). Chlorophylls I, chemistry and biochemistry of plant pigments. $2^{\text {éme }}$ edition.T.W.Goodwin. Academic press Edition. New York., 1-37.

Gardés-Albert, M. ; Bonnefont-Rousselot, D. ; Abedinzadeh, Z. et Jore, D. (2003). Especes reactives de l'oxygene. L'actualite chimique., 91-96.

Gill, S.S. and Tuteja, N. (2010). Reactive oxygen species and antioxidant machinery in abiotic stress tolerance in crop plants. Plant Physiol Biochem., 48 : 909-930.

Kamara, S. and Pflugmacher, S. (2006). Phragmites australis and Quercus robur leaf extracts affect antioxidative system and photosynthesis of Ceratophyllum demersum. Ecotoxicology and Environmental Safety., 67 : 240-246.

Leto, C. ; Tuttolomondo, T. ; La Bella, S. ; Leone, R. and Licata, M. (2013). Effects of plant species in a horizontal subsurface flow constructed wetland phytoremediation of treated urban wastewater with Cyperus alternifolius L. and Typha latifolia L. in the West of Sicily (Italy). Ecological Engineering., 6 : 282-291.

Mishra, S. ; Srivastava, S. ; Tripathi, R.D. ; Govindarajan, R. ; Kuriakose, S.V. and Prasad, M.N.V. (2006). Phytochelatin synthesis and response of antioxidants during cadmium stress in Bacopa monnieri L. Plant Physiol. Biochem., 44 : 25-37.

Moldes, D. ; Diaz, M. ; Tzanov, T. and Vidal, T. (2008). Comparative study of the efficiency of synthetic and natural mediators in laccase-assistes bleaching of eucalyptus kraft pulp, Bioresource Technology., 99 : 7959-7965.

N'goran, K.D. ; Koné, T. ; Yao, K.B. ; Adou, B.Y.Ch. ; Konan, Y.K.F. ; Kouadio, O.K.S. and Kouakou, T.H. (2019). Variation des Composés Phénoliques suite à 1'Elicitation du Cotonnier suivie d'Inoculation à Fusarium Oxysporum F. Sp. Vasinfectum. European Scientific Journal January., 15 :336.

Nadgórska-Socha, A.; Kafel, A.; Kandziora-Ciupa, M.; Gospodarek, J. and Zawisza- Raszka, A. (2012). Accumulation of heavy metals and antioxidant responses in Vicia faba plants grown on monometallic contaminated soil. Environmental Science and Pollution Research International., 20 : 1124-1134.

Parida, A.K. ; Das, A.B. ; Sanada, Y. and Mohanty, P. (2004). Effects of salinity on biochemical components of the mangrove, Aeceras corniculatum. Aquat Bot., $80: 77-78$.

Prost-Boucle, S. and Boutin, C. (2013). Etat des lieux national des zones de rejet végétalisées. EPNAC, p. 58.

Kim, D.O. ; Seng, W.J. and Lee, C.Y. (2003). Antioxidant capacity of phenolic phytochemicals from various cultivars of plums. Food Chemistry., 81 : 321-326.

Radic, S. ; Babic, M. ; Skobic, D. ; Roje, V. and Pevalek-Kozlina B. (2009). Ecotoxicological effects of aluminum and zinc on growth andantioxidants in 
Lemna minor L. Ecotoxicology and Environmental Safety., 10 : 1-4.

Riffat, J. ; Parvaiz, A. ; Kasturi, G. and Satyawati, S. (2007). Antioxidative response of Lemna polyrrhiza L to cadmium stress.J. Environ. Biol., 28 : 583-589.

Sbartai, I. ; Sbartai, H. ; Yaiche, F. ; Mokhtari, H. and Berrebbah, H. (2015). Induction of oxidative stress in wheat (Triticum aestivum L.) following infection by the pathogen of task halo (Pyrenophora trirtici-repentis), International Journal of Biosciences., 6 : 77-88.

Servais, S. (2004). Altération mitochondriale et stress oxydant pulmonaire en réponse à l'ozone : Effets de l'âge et d'une supplémentation en oméga-3. Thèse de Doctorat, Université Claude bernard- Lyon 1, France, p, 19-35.

Stone, K. (2009). Iris pseudacorus. In : Fire Effects Information System [Online]. U.S. Department of Agriculture, Forest Service, Rocky Mountain Research Station, Fire Sciences Laboratory. [2 December 2010] Available :

http://www.fs.fed.us/database/feis/

Sunohara,Y. and Matsumoto, H. (2008). Quinclorac-induced cell death is accompanied by generation of reactive oxygen species in maize root tissue. Phytochemistry., 69 : 2312-2319.

Suwasa, K. and Wanida, D. (2011). Domestic wastewater treatment by a constructed wetland system planted with rice. Environmental Science and Technology., 39 : 754-781.

Tlidjen, S. ; Meksem Amara, L. ; Bouchelaghem, S. ; Sbartai, H. and Djebar, M.R. (2012). Effects of the herbicide Calliofop 36EC on growth, antioxidant enzyme response and respiratory metabolism in two aquatic plant Elodea canadensis and Lemna minor. Advances in Environmental Biology., 6 : 2524-2530.

Triboit, F. ; Laffont-Schwob, I. ; Demory, F. ; Soulié-Märsche, I. ; Rabier J. ; Despréaux, M. and Thiéry, A. (2009). Heavy metal lability in porewater of highway detention pond sediments in South-Eastern France in relation to submerged vegetation. Water, Air, \& Soil Pollution., 209 : 229-240.

Tshala, U.J. ; Kitabala, M.A. ; Tunda, M.J.P. ; Mufind, K.M. ; Kalenda, M.A. ; Kapele, K.G. and Nyembo, K.L. (2017). Vers une valorisation des déchets ménagers en agriculture (péri) urbaine à Kolwezi : caractérisation et influence de la saisonnalité. Journal of Applied Biosciences., 112 : 11072-11079.

Vymazal, J. (2005). Horizontal sub-surface flow and hybrid constructed wetlands systems for wastewater treatment. Ecological Engineering., 25 : 478-490.

Wang, X.Y. ; Tang, H.B. and Paterson, A.H. (2011). Seventy million years of concerted evolution of a homoeologous chromosome pair, in parallel, in major poaceae lineages. Plant Cell., 23 :27-37.

Weckbecker, G. and Cory, J.G. (1998). Ribonucleotide reductase activity and growth of glutathione-depleted mouse leukemia L 1210 cells in vitro. Cancer Lett., 40 : 257- 264. 
Yadav, S.K. ; Dhote, M. ; Kumar, P. ; Sharma, J. ; Chakrabarti, T. and Juwarkar, A.A. (2010). Differential antioxidative enzyme reponses of Jatrofa curcas L to chromium stress. J. Hazard. Mater., 18 : 609-615.

Zaimeche, S. (2015). Contribution à l'étude de l'action d'agents polluants sur des végétaux bioindicateurs. Thèse de Doctorat. Université des Frères Mentouri Constantine-Algérie, p, 125.

Zou, J. ; Yu, K. ; Zhang, Z. ; Jiang, W. and Liu, D. (2009). Antioxidant response system and chlorophyll fluorescence in chromium (VI)- treated Zea mays L. Seedlings. Acta biologica cracoviensia Series Botanica., 51 : 23-33.

Zouainia, S. ; Djebar, M.R. ; Sbartai, H. ; Cherait, A. ; Khene, L. ; Kahli, H. and Berrebbah, H. ( 2016). Toxicologie impact assessement of cadmium on aquatic macrophyte : Elodea canadansis.Studia. Universitatis "Vasile Goldiş", Seria Ştiinţele Vieţii., 26 : 375-38. 